\title{
Kangaroo position: Immediate effects on the physiological variables of preterm and low birth weight newborns
}

\author{
Posição Canguru: efeitos imediatos nas variáveis \\ fisiológicas do recém-nascido pré-termo e baixo peso
}

\author{
Érica Cesário Defilipo ${ }^{[a]}$, Paula Silva de Carvalho Chagas ${ }^{[\mathrm{b}]}$, Caroline Chaves Lessa Nogueira ${ }^{[b]}$, \\ Geisiane Pereira Ananias ${ }^{[\mathrm{b}]}$, Andrea Januário da Silva ${ }^{[\mathrm{b}]^{*}}$
}

[a] Universidade Federal de Juiz de Fora (UFJF), Governador Valadares, MG, Brazil

[b] Universidade Federal de Juiz de Fora (UFJF), Juiz de Fora, MG, Brazil

\begin{abstract}
Introduction: The Kangaroo Mother Care (KMC) method is a significant neonatal alternative that ensures better quality humanized care for preterm and low birth weight newborns. Objective: To analyze the immediate physiological effects of the kangaroo position in critically ill newborns. Methods: Open clinical trial with parallel interventions, involving preterm (up to 28 days old) low or very low birth weight newborns (minimum weight of 1,250 grams) of both sexes, that were clinically stable and undergoing enteral nutrition. The degree of respiratory distress was assessed and quantified using the Silverman-Anderson scoring system. Heart rate and peripheral oxygen saturation were collected using a pulse oximeter. Respiratory rate was determined by auscultation for one minute. The newborns were submitted to the kangaroo position once only, for 90 minutes. Results: Participants were 30 newborns, $56.7 \%$ of which were girls. Comparison of the variables before and after application of the kangaroo position using the Wilcoxon test showed a statistically significant reduction in respiratory rate $(p=0.02)$ and Silverman-Anderson score $(p<0.01)$. The remaining variables showed no significant differences: heart rate $(p=0.21)$, peripheral oxygen saturation
\end{abstract}

\footnotetext{
* ECD: MS, email: erica.defilipo@ufjf.edu.br PSCC: PhD, email: paula.chagas@ufjf.edu.br CCLN: BS, email: krol_ufjf@yahoo.com.br GPA: BS, email: geiseananias@hotmail.com AJS: MS, email: andreajanu@yahoo.com.br
} 
$(p=0.26)$ and axillary temperature $(p=0.12)$. Conclusion: There was a decline in the respiratory rate and Silverman-Anderson score after application of the kangaroo position, while peripheral oxygen saturation, axillary temperature and heart rate remained stable.

Keywords: Kangaroo Mother Care. Premature. Low Birth Weight Newborn. Vital Signs. Neonatal Intensive Care Units.

\section{Resumo}

Introdução: $O$ Método Mãe Canguru apresenta grande importância na atualidade como uma alternativa ao cuidado neonatal que proporciona uma melhor qualidade na assistência, priorizando a humanização no atendimento do recém-nascido pré-termo e de baixo peso. Objetivo: Analisar os efeitos fisiológicos da posição canguru em recém-nascidos criticamente enfermos. Métodos: Ensaio clínico aberto com intervenções paralelas, no qual foram incluídos recém-nascidos pré-termo, com até 28 dias de vida, de baixo peso ou muito baixo peso ao nascer (peso mínimo de 1.250 gramas), de ambos os sexos, com estabilidade clínica e nutrição enteral. Para avaliar e quantificar o grau de desconforto respiratório foi utilizado o escore de Silverman-Anderson. A frequência cardíaca e a saturação periférica de oxigênio foram coletadas por meio do sensor de oximetria de pulso. A frequência respiratória foi avaliada através da ausculta durante um minuto. Os recém-nascidos foram submetidos à intervenção com a posição canguru em um único momento durante 90 minutos. Resultados: Participaram do estudo 30 recém-nascidos, sendo 56,7\% do sexo feminino. Ao comparar as variáveis antes e após a posição canguru, por meio do teste de Wilcoxon, foi observada redução estatisticamente significativa nas variáveis frequência respiratória $(p=0,02)$ e escore de Silverman-Anderson $(p<0,01)$. As demais variáveis não apresentaram diferenças significativas: frequência cardíaca $(p=0,21)$, saturação periférica de oxigênio $(p=0,26)$ e temperatura axilar $(p=0,12)$. Conclusão: Houve diminuição da frequência respiratória e do escore de Silverman-Anderson após a realização da posição canguru, além da manutenção da saturação periférica de oxigênio, da temperatura axilar e da frequência cardíaca.

Palavras-chave: Método Mãe-Canguru. Prematuro. Recém-nascido de Baixo Peso. Sinais Vitais. Unidades de Terapia Intensiva Neonatal.

\section{Introduction}

The continuous advances in neonatal technology in recent years have prompted an increase in survival rates among preterm and low birth weight newborns $[1,2]$. This represents an important public health problem, since 20 million preterm and low birth weight infants (under 2,500g) are born every year worldwide and about one third die in their first year due to respiratory problems, birth asphyxia and infections [2,3], while others may suffer from neuromotor developmental delays [4-6].

Most of these infants exhibit physiological abnormalities such as difficulties coordinating suction, swallowing and breathing, and are highly vulnerable to loss of heat and fluids, resulting in a high risk of neonatal death $[1,7,8]$.
Prematurity results in social and financial costs to families and society in general that are difficult to measure. Additionally, the expectations and anxieties inherent to preterm birth directly affect family structure, prompting the need to create a low-cost and efficient neonatal intervention plan to care for preterm newborns and their families [7, 9, 10].

In this context, the Kangaroo Mother Care (KMC) method is a significant neonatal alternative that ensures better quality humanized care for preterm and low birth weight infants $[2,7,10,11]$.

After intervention nutrition, less need with KMC, initial for oxygen, shorter improvement in the ventilation time, lower general condition of incidence of apnea, preterm newborns is greater weight gain, typically expressed shorter hospitalization in the form of better time and a decline 
in hospital infections $[1,11]$. There is also an improvement in the quality of life of both the mother and baby, culminating in an essential element of their affective relationship: the mother-baby bond $[7,11]$.

Almeida et al. [8], Miltersteiner et al. [12], Olmedo et al. [13] and Moore et al. [14] studied the effects of the kangaroo position on heart rate, respiratory rate, peripheral oxygen saturation, axillary temperature and mean blood pressure and found that KMC contributed to positive changes in the vital signs of premature newborns, promoting higher body temperature and increased peripheral oxygen saturation, thereby improving tissue oxygenation and reducing respiratory frequency.

Thukral et al. [15] reported better heart and respiratory rates as well as oxygen consumption in preterm and low birth weight newborns submitted to KMC when compared to infants that had to be separated from their mothers. Additionally, prolonged skin-to-skin contact between the mother and newborn infant promotes effective thermal control and may be associated with reduced risk of hypothermia [15].

Although the results of some studies differ in regard to the physiological variables, several authors have demonstrated the benefits of KMC, indicating that it can contribute to lowering mortality rates among preterm and low birth weight neonates $[1,15]$ by ensuring less need for ventilation and oxygen therapy, reducing the occurrence of apnea and facilitating weight gain [16 - 18].

As such, the aim of this study was to analyze the immediate physiological effects of the kangaroo position in critically ill newborns.

\section{Methods}

This was an open clinical trial with parallel interventions. All the newborns admitted to the neonatal intensive care unit of a public hospital in the municipality of Juiz de Fora, Minas Gerais (MG) state, between June and November 2013, and their respective mother/fathers, were invited to participate. The study was approved by the Research Ethics Committee under protocol number 295.470. The mothers and fathers were given information regarding the study and, after agreeing to participate, signed informed consent forms.

Those included in the study were preterm and low birth weight newborns of both sexes, up to 28 days old, who met the inclusion criteria for $\mathrm{KMC}$ according to the Ministry of Health [7]: minimum weight of 1,250 grams, clinical stability (breathing, hemodynamics and hematology), enteral feeding and mothers/fathers with sound physical and mental health.

Exclusion criteria were neonates that exhibited cardiac pathologies with hemodynamic repercussions, congenital malformations, genetic, metabolic and/or acquired syndromes, perinatal asphyxia, bronchopulmonary dysplasia, immediate need for surgery or those under mechanical ventilation.

Data were collected in four stages: 1) Selection of newborns according to the inclusion and exclusion criteria; 2) Collection of physiological variables before applying the kangaroo positions; 3) Application of the kangaroo position once only, on a single day, for 90 minutes; and 4) Collection of the variables immediately after application of the kangaroo position.

A form was used to select the newborns, which contained information on gestational and chronological age, sex, birth weight and weight at data collection, diagnoses, ventilator support and oxygen therapy, as well as information on the parents, such as color, marital status, family income and socioeconomic status classified according to the Brazilian Association of Market Research Companies (ABEP). These data were collected by analyzing the medical charts of the newborns.

The degree of respiratory comfort in the newborns was assessed and quantified using the Silverman-Anderson scoring system, which evaluates five different aspects: expiratory grunt, nasal flaring, intercostal retraction, xiphoid retraction and chest movements [19]. Each parameter is scored from 0 to 2 , with 0 indicating no changes; 1 minimal changes; and 2 marked changes. The total score (sum of the different scores) varies from 0 , demonstrating no respiratory distress, to 10 , indicating maximum respiratory distress [19].

The assessments were performed by two previously trained physiotherapists until intra-rater agreement showed reliability greater than 0.80 .

Heart rate and peripheral oxygen saturation were collected using a pulse oximeter connected to a DX2022 monitor (DIXTAL ${ }^{\circledR}$ ). Respiratory rate was assessed by auscultation for 1 minute using a stethoscope (Missouri ${ }^{\circledR}$ duoscopic - infant) and axillary temperature (degrees Celsius) with an underarm thermometer (TERMO MED INCOTTERM ${ }^{\circledR}$ LTDA - clinical digital thermometer). 
The infants were submitted to the kangaroo position once only for 90 minutes, in the early afternoon, in accordance with the treatment routine of the neonatal intensive care unit (NICU). This time was chosen because it was when the NICU was quietest. The kangaroo position involves placing the infant vertically between the mother's breasts, with his/her head turned sideways, arms flexed and adducted, held against the mother using fabric wrapped around them, taking care to avoid hyperextension of the head $[2,7]$.

The data were stored in a data base using Statistical Package for the Social Sciences (SPSS ${ }^{\circledR}$ ) software, version 14.0 for Windows.

Initial application of the Shapiro-Wilk test revealed that the data did not meet the criteria for normality. As such, nonparametric tests were used to analyze the significance of associations. The Wilcoxon test was applied to determine whether there was a change in the variables before and after the kangaroo position intervention. A significance level of $\alpha=0.05$ was set for all the analyses.

\section{Results}

During the data collection period, 36 newborn infants met the inclusion criteria established for the study. Three were unable to participate because the mother was hospitalized during the data collection period, two were excluded due to legal issues that prevented contact between the mother and child and one because the guardian had to interrupt the kangaroo position before completing the stipulated time.

Participants were 30 newborns, $56.7 \%$ of which were girls. According to gestational age classification, $66.7 \%$ of the subjects were between 32 and 34 weeks old. With respect to birth weight, $83.3 \%$ were considered to have low birth weight $(\leq 2,500 \mathrm{~g})$ and $16.7 \%$ very low birth weight $(\leq 1,500 \mathrm{~g})$. Mothers were the main caregivers who performed the kangaroo position, and only two fathers participated in the study; all those who carried out KMC intervention with the newborns did so for the first time.

The participants were classified as belonging predominantly to socioeconomic class C (53.3\%), according to ABEP criteria. The descriptive characteristics for the participants are shown in Table 1.
Table 1 - Descriptive characteristics of the participants

\begin{tabular}{|c|c|c|}
\hline Variables & $f$ & (\%) \\
\hline \multicolumn{3}{|c|}{ Characteristics of the Mother/Father } \\
\hline \multicolumn{3}{|l|}{ Color } \\
\hline White & 12 & $(40.0)$ \\
\hline Brown & 7 & $(23.3)$ \\
\hline Black & 10 & (33.3) \\
\hline Yellow & 1 & (3.3) \\
\hline \multicolumn{3}{|l|}{ Marital Status } \\
\hline Single & 13 & $(43.3)$ \\
\hline Married & 8 & $(26.7)$ \\
\hline Common-law marriage & 4 & $(13.3)$ \\
\hline Other & 5 & $(16.7)$ \\
\hline \multicolumn{3}{|l|}{ Socioeconomic status } \\
\hline $\mathrm{B} 1 / \mathrm{B} 2$ & 11 & $(36.6)$ \\
\hline $\mathrm{C} 1 / \mathrm{C} 2$ & 16 & $(53.3)$ \\
\hline D & 3 & $(10.0)$ \\
\hline \multicolumn{3}{|l|}{ Family Income } \\
\hline Up to 1 minimum wage & 9 & $(30.0)$ \\
\hline 2 to 4 minimum wages & 21 & $(70.0)$ \\
\hline \multicolumn{3}{|c|}{ Characteristics of the Newborn } \\
\hline \multicolumn{3}{|l|}{ Sex } \\
\hline Female & 17 & $(56.7)$ \\
\hline Male & 13 & $(43.3)$ \\
\hline \multicolumn{3}{|l|}{ GA Classification } \\
\hline$\leq 28$ weeks & 1 & (3.3) \\
\hline 29 to 31 weeks & 3 & $(10.0)$ \\
\hline 32 to 34 weeks & 20 & $(66.7)$ \\
\hline$\geq 35$ weeks & 6 & $(20.0)$ \\
\hline \multicolumn{3}{|l|}{ BW Classification } \\
\hline VLBW & 5 & (16.7) \\
\hline LBW & 25 & (83.3) \\
\hline
\end{tabular}

Note: $f=$ frequency; $G A=$ Gestational Age; $B W=$ Birth Weight; VLBW $=$ Very low birth weight $(\leq 1,500 \mathrm{~g})$; LBW $=$ Low birth weight $(\leq 2,500 \mathrm{~g})$.

Table 2 displays the clinical changes exhibited by the study population.

Table 2 - Diagnoses exhibited by the newborns under study

\begin{tabular}{lcc}
\hline Clinical Changes & $\boldsymbol{f}$ & (\%) \\
\hline Sepsis & 16 & $(53.3)$ \\
Respiratory Distress & 10 & $(33.3)$ \\
IRDS & 8 & $(26.7)$ \\
Hypoglycemia & 3 & $(10.0)$ \\
Neonatal jaundice & 2 & $(6.7)$ \\
NB exposed to HIV & 2 & $(6.7)$ \\
\hline
\end{tabular}

Note: $f=$ frequency; IRDS = Infant Respiratory Distress Syndrome; NB = newborn; HIV = Human Immunodeficiency Virus. 
A total of $56.7 \%$ of newborns required noninvasive mechanical ventilation for a maximum of seven days prior to application of the kangaroo position. The remaining types of ventilatory support and mean days of use ( \pm standard deviation) are described in Tables 3 and 4.

Table 3 - Types of ventilatory support used prior to KMC

\begin{tabular}{lcc}
\hline Ventilatory support & $\boldsymbol{f}$ & (\%) \\
\hline Noninvasive ventilation & 17 & 56.7 \\
Invasive Mechanical Ventilation & 5 & 16.7 \\
Oxygen via NC/Incubator & 9 & 30.0 \\
Oxygen hood & 5 & 16.7 \\
\hline
\end{tabular}

Note: $\mathrm{KMC}=$ Kangaroo Mother Care method; $f$ = frequency; $\mathrm{NC}=$ nasal catheter.

The mean gestational age was 33 weeks (minimum 28 weeks) and mean birth weight was 1843 grams (minimum weight 1080 grams). The mean and standard deviation values are shown in Table 4.

Table 4 - Descriptive analysis of the continuous variables

\begin{tabular}{lcc}
\hline Variables & Mean & SD \\
\hline GA & 33.23 & 1.96 \\
$\mathrm{BW}$ & 1843.2 & 373.4 \\
$\mathrm{MV}$ (days) & 0.50 & 1.53 \\
$\mathrm{IMV}$ (days) & 1.43 & 1.89 \\
$\mathrm{O}_{2}$ Hood (days) & 0.77 & 2.36 \\
$\mathrm{O}_{2}$ by NC/incubator (days) & 0.57 & 1.07 \\
\hline
\end{tabular}

Note: $\mathrm{SD}=$ Standard deviation; $\mathrm{GA}=$ Gestational Age; $\mathrm{BW}=$ Birth Weight; $\mathrm{MV}=$ Mechanical Ventilation; NMV = Noninvasive Mechanical Ventilation; $\mathrm{O}_{2}=0 \mathrm{xygen} ; \mathrm{NC}=$ Nasal Catheter.

Comparison of the variables before and after application of the kangaroo position using the Wilcoxon test showed a statistically significant reduction in respiratory rate $(p=0.02)$ and Silverman-Anderson score $(\mathrm{p}<0.01)$. The mean, standard deviation and p-values are displayed in Table 5.
Table 5 - Comparison of the variables before and after the kangaroo position

\begin{tabular}{ccccc}
\hline Variables & Group & Mean & SD & p-value \\
\hline \multirow{2}{*}{$\mathrm{HR}$} & Before & 142.43 & 25.13 & \multirow{2}{*}{0.21} \\
& After & 149.4 & 21.08 & \\
$\mathrm{RR}$ & Before & 46.0 & 9.38 & $0.02^{*}$ \\
& After & 41.63 & 9.74 & \\
$\mathrm{Sp0} 2$ & Before & 95.1 & 2.73 & 0.26 \\
& After & 95.53 & 2.66 & \\
$\mathrm{~T}{ }^{\circ} \mathrm{C}$ & Before & 36.46 & 0.51 & \multirow{2}{*}{0.12} \\
& After & 36.58 & 0.40 & \\
\multirow{2}{*}{$\mathrm{SAS}$} & Before & 0.93 & 0.64 & $<0.01^{*}$ \\
& After & 0.43 & 0.68 & \\
\hline
\end{tabular}

Note: $S D=$ Standard Deviation; $p$-value $=$ statistical significance level; $\mathrm{HR}=$ Heart Rate; FR $=$ Respiratory Rate; $\mathrm{SpO}_{2}=$ Peripheral Oxygen Saturation; $\mathrm{T}^{\mathrm{O}} \mathrm{C}=$ Axillary temperature; $\mathrm{ESA}=$ SilvermanAnderson score* $p<0.05$.

\section{Discussion}

Implementation of the kangaroo mother care method in clinical practice is vital for premature newborns and their families. This study aimed to assess the physiological effects of the kangaroo position on critically ill newborns and demonstrated a statistically significant decline in respiratory frequency and the degree of respiratory distress, according to the Silverman-Anderson scoring system. The technique also stabilized peripheral oxygen saturation, axillary temperature and heart rate, which may mean that KMC could maintain the clinical stability of preterm and low birth weight newborns [8, 12 - 14, 20].

The population under study exhibited characteristics typical of premature and low birth weight neonates, such as the need for ventilatory support and clinical problems, particularly breathing difficulties, sepsis and infant respiratory distress syndrome (IRDS). According to the World Health Organization (WHO), preterm newborns are especially vulnerable to infections and breathing difficulties, in addition to exhibiting unstable 
body temperature, hypoglycemia and sucking problems [1], due to the immaturity of the body's different systems as a result of their premature birth $[1,7]$. In this case, KMC can promote beneficial physiological changes in preterm and low birth weight infants, contributing significantly to their physiological stability $[7,8]$.

The KMC method does not stipulate a time in which the newborn should remain in the kangaroo position, but rather it is left to the parents to decide [7]. The time of 90 minutes specified in this study is in accordance with the Ministry of Health, which recommends that newborns remain in the position for at least an hour to allow them to relax and fall into a deep sleep, essential for their recovery and brain development [7]. Boju et al. [21] found that application of the kangaroo position for one hour was sufficient to obtain beneficial physiological effects in preterm newborns. According to Thukral et al. [15], the kangaroo position should be maintained for as long as possible (at least one or two hours), according to the infant's tolerance.

In light of the results obtained, it can be inferred that the kangaroo position significantly reduced respiratory rate and the Silverman Anderson score. Almeida et al also observed a decline in the respiratory rate in a study that assessed 22 premature and low birth weight newborns evaluated after thirty minutes in a crib and thirty minutes in the kangaroo position over three consecutive days.

The same result was observed by Van Zanten et al. [20], who evaluated 34 premature neonates under ventilator support every 5 minutes, before, during and after application of KMC. The kangaroo and prone positions promote stabilization of the ribs, allowing better synchronization between the diaphragm and stomach muscles, and determine the expansion of dorsal alveolar segments, which are more prone to atelectasis in the supine position, thereby increasing the volume available for ventilation and improving respiratory performance $[13,22]$.

Moore et al. (140 conducted a meta-analysis of 29 randomized controlled trials that used the kangaroo position and found a decline in respiratory rate of five breaths per minute, corroborating the findings of this study, whereby the mean respiratory rate of the newborns decreased from 46.07 to 41.63 breaths per minute.

Boju et al. [21] studied 83 preterm newborns after application of the kangaroo position and also found that their respiratory rate declined, more so in premature girls.

This decrease in the respiratory rate could also be explained by the position's potential to promote deep sleep and relaxation. Deep sleep is known to favor development, particularly of the brain, because it allows the body to rest and conserve energy, enabling neural synapses to mature and remodel, particularly in preterm newborns $[13,22]$.

According to research by Azevedo et al. [23] and Bauer et al. [17], the kangaroo position favors a state of deep quiet sleep. Azevedo et al. [23] studied 44 newborns weighing less than 1,500 g under mechanical ventilation before, during and after application of KMC and observed that the position favored sleep, especially deep sleep. In the study by Bauer et al. [17] 27 premature infants (25 to 30 weeks) who were breathing on their own exhibited longer sleep duration during KMC when compared to controls.

In addition to a reduced respiratory rate, the results also showed a significant decline in the Silverman-Anderson score, a useful and widely used tool to assess and identify respiratory distress in newborns [19].

Miltersteiner et al. [12] found that the prone position was the most similar to the vertical position used in KMC. Much like the kangaroo position, sleeping on the stomach (prone position) allows for better chest and diaphragm expansion, evident in the raising of the ribs and sternum.

Thus, the kangaroo position favors the mechanics of breathing, reducing respiratory difficulties. A reduction in the Silverman-Anderson score following KMC, as observed in this study, combined with a decline in the breathing rate may indicate an improvement in the respiratory status of newborns $[12,24]$.

The baseline heart rate of newborns averages from 120 to 160 beats per minute [25]. In this study, the heart rate remained within the normal range (average of 150 beats per minute), as reported by Almeida et al. [8], who assessed preterm and low birth weight newborns before and after the kangaroo position and observed a stable heart rate, with no significant difference in this variable.

By contrast, Boju et al. [21] reported a significant difference in heart rate after one hour in the kangaroo position, which declined by an average of three beats per minute in preterm newborns 
infants and five beats in neonates that were small for their gestational age. Azevedo et al. [26] studied 43 premature newborns with a birth weight lower than 1,500 grams under mechanical ventilation and also observed a significant reduction (five beats per minute) in their heart rate during KMC. The authors reported that this change was not clinically significant, and the decline was due to the greater comfort and relaxation provided by the kangaroo position.

They also observed stable peripheral oxygen saturation, with mean values of approximately 95\%. Similar results were recorded by Olmedo et al. [13], who analyzed 20 premature neonates, 10 in both the kangaroo position and prone position group, applying the positions for 60 minutes, and found that the former position produced no differences in peripheral oxygen saturation over the three days of treatment.

By contrast, other results indicate an increase in this variable, as reported by Miltersteiner et al. [12], who studied 23 premature neonates before and after the kangaroo position and found an increase in peripheral oxygen saturation after application of the position (12). Boju et al. [21] observed a 1.1\% rise in peripheral oxygen saturation in preterm newborns, $2.1 \%$ in neonates small for their gestational age and $1.5 \%$ in female newborns.

Premature infants have difficulty regulating their body temperature, owing to their immature nervous system, inadequate heat production and sweating caused by their relatively large body surface in relation to their weight, low thermal insulation, in addition to their low body weight to produce heat and regulate/maintain body temperature [2].

According to the WHO, prolonged skin-toskin contact between a mother and her newborn infant is efficient in controlling temperature and may be associated with a reduced risk of hypothermia [3]. Almeida et al. [8] found that the kangaroo position helped regulate the body temperature of newborns, reducing episodes of apnea and favoring weight gain.

Casati, Oliveira and Paula [27] carried out a systematic literature review and concluded that KMC helps maintain the body temperature of preterm newborns, preventing the harmful consequences of heat loss. Tuoni et al. [28] studied 213 premature neonates with birth weight lower than or equal to
$1,500 \mathrm{~g}$ divided into two groups, one submitted to the kangaroo method and the other to conventional care. Based on the results obtained, the authors reported that KMC is efficient in promoting thermal protection.

As observed in the present study, Olmedo et al. [13] found no significant difference in temperature between the intervention and control groups in 20 preterm newborns after KMC.

Ibe et al. [29] studied 13 newborn infants weighing less than 2,000 grams by comparing the results of 38 four-hour sessions of KMC to 38 sessions of conventional care in an incubator. The findings demonstrated a $90 \%$ decline in the risk of hypothermia when the kangaroo position was used compared to conventional care.

The limitations of this study include the lack of a control group for comparison purposes and calculation of the sample size; however, all the newborns that met the inclusion and exclusion criteria during the data collection period were invited to participate.

This study aimed to arouse interest in applying the kangaroo position in the chosen neonatal intensive care unit, encouraging continued use of the method by the healthcare professionals and parents involved based on their knowledge of its benefits. Additionally, it is believed that the results obtained here benefitted the health of mothers/fathers and the newborns by encouraging breastfeeding and skin-to-skin contact, culminating in an essential element of the affective relationship: the motherbaby bond. Use of the Kangaroo Mother Care method in neonatal intensive care units should be encouraged, in line with Ministry of health guidelines, in order to ensure better quality and more humanized care for preterm and low birth weight newborns and their mothers.

\section{Conclusions}

There was a statistically significant decline in the respiratory rate and Silverman-Anderson score of premature and low birth weight newborns after application of the kangaroo position. Additionally, the technique also stabilized peripheral oxygen saturation, axillary temperature and heart rate, indicating that KMC could maintain the clinical stability of critically ill neonates. 


\section{Acknowledgments}

The authors are grateful to the National Council for Scientific and Technological Development (CNPq) and the Federal University of Juiz de Fora (UFJF) for the scientific initiation scholarships.

\section{References}

1. World Health Organization (WHO). Born too soon: the global action report on preterm birth. Geneva: World Health Organization; 2012. p. 60-77.

2. Brasil. Ministério da Saúde. Secretaria de Políticas de Saúde. Área de Saúde da Criança. Atenção humanizada ao recém-nascido de baixo peso: método mãecanguru: manual do curso. 1st ed. Brasília: Ministério da Saúde; 2002. p.11-73.

3. Organización Mundial de la Salud, Departamento de Salud Reproductiva e Investigaciones Conexas. Método madre canguro: guia práctica. Genebra: Biblioteca de la OMS; 2004. p.1-9.

4. Silva AJ, Neves LAT, Frônio JS, Ribeiro LC. Factors related to motor developmental delay of newborns. Rev Bras Crescimento Desenvolv Hum. 2014;24(3):320-7.

5. Rodrigues OMPR, Bolsoni-Silva AT. Efeitos da prematuridade sobre o desenvolvimento de lactentes. Rev Bras Crescimento Desenvolvimento Hum. 2011;21(1):111-21.

6. Lemos RA, Frônio JS, Ribeiro LC, Demarchi RS, Silva J, Neves LAT. Desempenho funcional segundo a idade gestacional e o peso ao nascer de crianças em idade pré-escolar nascidas prematuras ou com baixo peso. Rev Bras Crescimento Desenvolv Hum. 2012;22(1):1-11.

7. Brasil. Ministério da Saúde. Secretaria de Atenção à Saúde. Departamento de Ações Programáticas Estratégicas. Atenção humanizada do recém-nascido de baixo peso: Método Canguru: manual técnico. 2nd ed. Brasília: Editora do Ministério da Saúde; 2013. p.7-25.

8. Almeida CM, Almeida AFN, Forti EMP. Efeitos do método mãe canguru nos sinais vitais de recémnascidos pré-termo de baixo peso. Rev Bras Fisioter. 2007;11(1):1-5.
9. Ruiz-Peláez JG, Charpak N, Cuervo LG. Kangaroo Mother Care, an example to follow from developing countries. BMJ. 2004;329(7475):1179-81.

10. Ramos HAC, Cuman RKN. Fatores de risco para prematuridade: pesquisa documental. Esc Anna Nery. 2009;13(2):297-304.

11. Freitas JO, Camargo CL. Discutindo o cuidado ao recémnascido e sua família no Método MãeCanguru. Rev Bras Crescimento Desenvolv Hum. 2006;16(2):88-95.

12. Miltersteiner AR, Miltersteiner DR, Rech VV, Molle LD. Respostas fisiológicas da posição mãe canguru em bebês pré-termo, baixo peso e ventilando espontaneamente. Rev Bras Saude Mater Infant. 2003;3(4):447-55.

13. Olmedo MD, Gabas GS, Merey LSF, Souza LS, Muller KTC, Santos MLM, et al. Respostas fisiológicas de recém-nascidos pré-termo submetidos ao Metódo Mãe-Canguru e a posição prona. Fisioter Pesqui. 2012;19(2):115-21.

14. Moore ER, Anderson GC, Bergman N, Dowswell T. Early skin-to-skin contact for mothers and their healthy newborn infants. Cochrane Database Syst Rev. 2012;5:CD003519.

15. Thukral A, Chawla D, Agarwal R, Deorari AK, Paul VK. Kangaroo mother care - an alternative to conventional care. Indian J Pediatr. 2008;75(5):497-503.

16. Silva JR, Thomé RC, Abreu RM. Método mãe canguru nos hospitais / maternidades públicos de Salvador e atuação dos profissionais da saúde na segunda etapa do método. Rev CEFAC. 2011;13(3):522-33.

17. Bauer K, Pyper A, Sperling P, Uhrig C, Versmold H. Effects of gestational and postnatal age on body temperature, oxygen consumption, and activity during early skin-to-skin contact between preterm infants of 25-30-week gestation and their mothers. Pediatr Res. 1998;44(2):247-51.

18. Venâncio SI, Almeida H. Método mãe canguru: aplicação no Brasil, evidências científicas e impacto sobre o aleitamento materno. J Pediatr. 2004;80 (5 Suppl):s173-80.

19. Mathai SS, Raju U, Kanitkar M. Management of Respiratory Distress in the Newborn. Med J Armed Forces India. 2007; 63(3):269-72. 
20. van Zanten HA, Havenaar AJ, Stigt HJH, Ligthart PAH, Walther FJ. The kangaroo method is safe for premature infants under 30 weeks of gestation during ventilatory support. J Neonatal Nurs. 2007;13(5):186-90.

21. Boju SL, Krishna MG, Uppala R, Chodavarapu P, Chodavarapu R. Short spell kangaroo mother care and its differential physiological influence in subgroups of preterm babies. J Trop Pediatr. 2012;58(3):189-93.

22. Bruno F, Piva JP, Garcia PCR, Einloft P, Fiori R, Barreto SM. Efeito a curto prazo da posição prona na oxigenação de crianças em ventilação mecânica. J Pediatr. 2001;77(5):361-8.

23. Azevedo VMGO, David RB, Xavier CC. Cuidado mãe canguru em recém-nascidos pré-termo sob suporte ventilatório: avaliação dos estados comportamentais. Rev Bras Saude Mater Infant. 2011;11(2):133-8.

24. Kimura AF, Yoshitake APM, Bueno M, Belli MAJ. Avaliação da função respiratória do recém-nascido no período neonatal imediato. Rev Bras Enferm. 2009;62(6):850-5.

25. Brasil. Ministério da Saúde. Secretaria de Atenção à Saúde. Departamento de Ações Programáticas e Estratégicas. Atenção à saúde do recém-nascido: guia para os profissionais de saúde. $1^{\text {st }}$ ed. Brasília: Ministério da Saúde; 2011. p.72-4.
26. Azevedo VM, Xavier CC, Gontijo FO. Safety of Kangaroo Mother Care in intubated neonates under 1500 g. J Trop Pediatr. 2012;58(1):38-42.

27. Casati PS, Oliveira CS, Paula S. Método mãe canguru e suas associações nos benefícios dos recém-nascidos baixo peso. Uniciências. 2010;14(1):135-46.

28. Tuoni C, Scaramuzzo RT, Ghirri P, Boldrini A, Bartalena L. Kangaroo Mother Care: four years of experience in very low birth weight and preterm infants. Minerva Pediatr. 2012;64(4):377-83.

29. Ibe OE, Austin T, Sullivan K, Fabanwo O, Disu E, Costello AM. A comparison of kangaroo mother care and conventional incubator care for thermal regulation of infants $<2000 \mathrm{~g}$ in Nigeria using continuous ambulatory temperature monitoring. Ann Trop Paediatr. 2004;24(3):245-51.

Received on $05 / 28 / 2016$

Recebido em 28/05/2016

Approved on 09/18/2017

Aprovado em 18/09/2017 